\title{
THE CONTRACT OF EMPLOYMENT IN LABOUR LAW: OBSTACLE OR PANACEA?
}

\author{
Radley Henrico \\ BProc LLB \\ LLM Student, University of Johannesburg \\ Member of the Johannesburg Bar \\ Nicola Smit \\ BLC LLB LLD \\ Professor in Mercantile Law \\ University of Johannesburg
}

\begin{abstract}
SUMMARY
The disparity of power in the employment relationship has courted argument that this imbalance continues to be perpetuated in the guise of "the contract of employment", thereby rendering the contract of employment irrelevant and ineffective in advancing labour law rights. This article counters this view by illustrating the changed nature of the traditional foundation of the employment relationship, known as the contract of employment. The advent of a constitution and our courts' willingness to develop and strengthen rights and obligations arising from the contract of employment are considered. In addition, the impact of legislation, collective bargaining and the recent more purposive interpretation of the statutory definition of "employee" are discussed. The writers conclude that, although the contract of employment is not a panacea to the employment relationship, it is useful and expedient when interpreted and enforced against the backdrop of constitutional imperatives.
\end{abstract}

INTRODUCTION

Whether the contract of employment is still relevant today and acts as an admission ticket for labour law rights or, rather, as an insurmountable hurdle to such rights is a question that requires discussion against the back-drop of the following (well-known) assertion:

"But the relation between an employer and an isolated employee or worker is typically a relation between a bearer of power and one who is not a bearer of power. In its inception it is an act of submission, in its operation it is a condition of subordination, however much the submission and the subordination may be concealed by that indispensable figment of the legal mind known as the contract of employment'."

Davies and Freedland Kahn-Freund's Labour and the Law (1983) 18. See also Rycroft and 247 
The disparity of power in the employment relationship has courted argument ${ }^{2}$ that this imbalance continues to be perpetuated in the guise of "the contract of employment", thereby rendering the contract of employment irrelevant $^{3}$ and ineffective in advancing labour law rights. ${ }^{4}$ The countercontention, however, is that the contract of employment is "the cornerstone of the edifice of labour law". ${ }^{5}$ It will be argued in this contribution that the contract of employment does in fact have relevance which can be gauged in terms of its overall relative effective purpose and usefulness in advancing labour rights of the contractual parties within the labour framework system as a whole.

Jordaan A Guide to South African Labour Law 2ed (1992) 19 fn 113. For an interesting discussion on the evolution of the master-servant relationship as established in the United Kingdom in the Elizabethan era under the Statute of Artificers of 1563 see Deakin "The Contract of Employment: Study in Legal Evolution" 19 http://www.cbr.cam.ac.uk/pdfWP 203.pdf (accessed 2009-10-05).

2 In this regard see in general Vettori The Employment Contract and the Changed World of Work 1ed (2007) 2; Kahn-Freund Labour and the Law (1977) 6; Beatty "Constitutional Labour Rights: Pros and Cons" 1993 ILJ 1 4; Olivier "The Relevance of Status and Contract for the Employment Relationship (Part I)" (adapted version of an inaugural address delivered on 2 September 1992 at the Rand Afrikaans University, as it was then known) 15; and Macken, McCarry and Sappideen The Law of Employment (1997) 73.

3 To adopt the argument by Ridout as referred to in Elias "The Structure of the Employment Contract" 1982 CLP 95. See also Olivier in fn 2 above; Davies and Freedland 18 and 25; and Clark "Towards a Sociology of Labour Law: An Analysis of the German Writings of Otto Kahn-Freund" in Lord Wedderburn of Charlton, Clark and Lewis Labour Law and Industrial Relations: Building on Kahn-Freund (1983) 82-83, 94 and 99.

4 In relation to both employees and employers but more particularly employees (both typical and atypical) who require protection against exploitation from the superior bargaining power of the employer. See Brodie "Mutual Trust and Confidence: Catalysts, Constraints and Commonality" 200837 ILJ (UK) 329 342; and Vettori 157 et seq. See also Thompson and Benjamin SA Labour Law Vol 1 (loose-leaf) AA1-3: "Our common law entrenches notions of property dominant in an earlier era, particularly in the priority it accords to the rights of private landowners and asset-holders. At the same time, the contract of employment represent $(\mathrm{sic})$ a rather inflexible package when viewed against the demands of modern employment relations. Contemporary labour law challenges these established legal precepts by asserting broader public interest and economic considerations. Collective bargaining, for instance, is presented as a social good, justifying incursions into private territory. The tension between nineteenth-century common law and twentieth-century statute law is reflected in the often contrasting judgments of ordinary courts and more specialized labour courts on employment matters. Unhappily, the lawgiver has accorded the ordinary courts and the labour courts overlapping jurisdictions in certain areas. Coherence in the labour jurisprudence has suffered as a result and further reform of the law in this regard is keenly awaited."

5 See Fourie "Status en Kontrak in die Suid-Afrikaanse Arbeidsreg" 1979 THRHR 79 85; and Epstein "In Defense of the Contract at Will" 1984 University of Chicago LR 947948982. The contract of employment has also been referred to as "a remarkable social and economic institution as important as the invention of limited liability for companies". See Deakin, in particular fn 123 http://www.cbr.cam.ac.uk/pdfWP 203.pdf (accessed 2009-1005). 
ADVANTAGES OF DEFINING LABOUR LAW RIGHTS IN TERMS OF A CONTRACT

\section{The establishment and termination of employment}

The day-to-day dynamics of the commercial, industrial and economic domain of our society testify to countless instances of individuals entering into contracts of employment. ${ }^{6}$ The law of contract in general has been described as being of "fundamental importance in the modern world" on account of its innate closeness with every form of economic activity; ${ }^{8}$ no less so, it is submitted, in the realm of employment. ${ }^{9}$ This is true regardless of the special nature of the employment relationship. In the matter of White $v$ Pan Palladium SA (Pty) $L t d^{10}$ the court, referring to NUMSA $\vee$ Borg-Warner SA (Pty) Ltd, ${ }^{11}$ correctly pointed out that in the absence of the parties having agreed on all the material terms, an employment relationship may still exist in terms of the statutory definition provided and therefore the relationship is not dependent on the conclusion of a contract "recognised at common law as valid and enforceable". ${ }^{12}$ Recently in MEC, Department of Health, Eastern Cape $v$

$6 \quad$ Written or oral, and in respect of which no particular formalities are a requirement, save for the exceptions pointed out by Wallis in Labour and Employment Law (1995) 2-21 fn 1. Cornelius Principles of the Interpretation of Contracts in South Africa (2007) 3 states that: "In our law, as in most civilised legal systems today, agreement forms the basis on which contracts are concluded. Without agreement, there can be no contract. In general, the existence of consensus is determined subjectively." See also Church of the Province of Southern Africa (Diocese of Cape Town) v CCMA [2001] 11 BLLR 1213 (LC) par 28: "A contract must of course be entered into freely and voluntarily with both parties being fully aware of the duties to which they have agreed. The only restriction is that a contract must not be one which is forbidden by statute or is contra bonos mores. A contract may be written or oral, express or tacit. In the case of an employment contract Grogan ... quite correctly states that what is required between the parties is a voluntary agreement with one party agreeing to perform certain specified and/or implied duties for the other for an indefinite period, and to be commanded to carry out such duty in a particular way for a fixed or ascertainable wage .... There are no formalities that are required to be complied with for the formation of an employment contract."

7 Christie The Law of Contract (2001) 1, in particular fn 1. See Kilian "Legal, Economic and Dispute-resolution Principles for a Forward Contract ... Who Knows?" 2007 THRHR 391. See also Pearmain "Contracting for Socio-economic Rights: A Contradiction in Terms? (1)" 2006 THRHR 287 293. A brief historical synopsis is provided by Kleyn "The Reality of Real Contracts" 1995 THRHR 16 26. For interesting reading on the constitutional protection afforded employees under international employment contracts see Calitz "Globalisation, the Development of Constitutionalism and the Individual Employee" PER/PELJ 10 2/115 http://www.puk.ac.za/opencms/export/PUK/htm (accessed 2009-10-09).

8 See Hawthorne "Relational Contract Theory, Principles of European Contract Law - Longterm Contracts, and the Impact of Implicit Dimensions" 2007 THRHR 371. Cf Collins "Market Power, Bureaucratic Power, and the Contract of Employment" 1986 ILJ (UK) 12 ; and Rycroft and Jordaan 21 et seq. See also Wedderburn "Labour Law, Corporate Law and the Worker" 1993 ILJ 517523.

9 That it is competent for a court to grant an order of specific performance of a contract of employment, see Santos Professional Football Club (Pty) v Igusund 20035 SA 73 (C); and Nationwide Airlines (Pty) Ltd v Roediger 20081 SA 293 (WLD) [21]

10 20056 SA 384 (LC).

19943 SA 15 (A).

391B-C. 
Odendaal ${ }^{13}$ the labour court, in referring to the "hybrid quality" which the contract of employment has assumed with reference to factors such as status, collective bargaining and social legislation, stated that the conclusion of the contract of employment was indicative of the commencement of the employment relationship. ${ }^{14}$

It must, however, be noted that, as illustrated clearly in the Borg-Warner case, the existence of a contract of employment is relevant but not indispensable to establish an employment relationship. Similarly, in the event of the dismissal of an employee the termination of a contract of employment may be relevant but is, once again, not obligatory. ${ }^{15}$ If one should therefore pose the question whether an employment relationship can exist without the conclusion of a contract of service, the answer seems that it is indeed possible. ${ }^{16}$ This does not mean, however, that there can be an employment relationship where the parties to the relationship did not intend there to be

13 [2009] 5 BLLR 470 (LC) [29]-[50]. A new contract of employment was drawn up by the applicant containing the amended terms and conditions of employment of the district surgeons. Of the 43 doctors who were requested to sign the new contracts of employment, four refused to do so. A dispute existed regarding whether department's conduct constituted an unfair and unlawful attempt to change unilaterally the terms and conditions of employment or, rather, in terms of the original contracts of employment signed by the district surgeons, whether the department was entitled to amend the contracts of the district surgeons.

14 See par 49: "Historically, at least, it has been accepted that the contract of employment signalled the commencement of the employment relationship between the employer and the employee. Once the two contracting parties have agreed on the core elements of the employment contract, which is an agreement that the employee will place his or her labour at the disposal, and under the control of the employer in exchange for some form of remuneration, the employment relationship will be created. Influences such as globalisation, the introduction of social legislation and collective bargaining, which all have a profound impact on the employment relationship, have, however, forced courts and academic writers to rethink the role of traditional contractual principles in the employment relationship and more in particular the interaction between traditional contractual principles and applicable legislation."

15 See s 186(1)(e) of the Act (selective re-employment of employees); and MEC, Department of Health, Eastern Cape $v$ Odendaal supra (par 49): "Although it is accepted that the contract of employment has taken on a more hybrid quality as a result of the fact that labour and social legislation as well as collective bargaining often supersede, expand and in many instances limit the rights and obligations of the respective contracting parties (particularly in order to protect the employee who is, in most instances, the vulnerable contracting party), the conclusion of the contract of employment nonetheless, in my view, signifies the commencement of the employment relationship. It would therefore follow that the termination of the contract of employment would also signify the end of the employment relationship."

16 S 213 of the Act defines an "employee" as: "(a) Any person, excluding an independent contractor, who works for another person or for the State and who receives, or is entitled to receive, any remuneration; and (b) Any other person who in any manner assists in carrying on or conducting the business of an employer." Act 75 of 1997 and Act 55 of 1998 make use of the exact same definition. In Discovery Health Limited v CCMA [2008] 7 BLLR 633 (LC) the court stated that (par 6): "It is immediately apparent that the terms of the definition do not refer [sic] directly and make reference to a contract of employment. Despite this, the courts have interpreted the definition narrowly, so as to apply it only to persons engaged in terms of a common law contract of employment (see Smit $v$ Workmen's Compensation Commissioner 19791 SA 51 (A)). Much of the jurisprudence concerned with interpreting the definition, viewed as it has been through the lens of the law of contract, has accordingly sought to establish a touchstone by which an employment contract can be defined." 
one. In this regard the Church of the Province of Southern Africa (Diocese of Cape Town) case $^{17}$ held that: ${ }^{18}$

"the purpose of the second leg of the definition is: "to make clear that in certain circumstances a person may be employed by another within the meaning of the Act even in the absence of an employment contract between them.' I cannot accept that the definition of employee seeks to enforce employment contracts where this was not intended by the parties. In interpreting provisions similar to the definition as presently exist in the LRA the old Labour Appeal Court in the matter of Liberty Life Association of Africa Ltd $v$ Niselow (1996) 17 ILJ 660 (LAC) recognised the need to restrict the apparent scope of the wording to avoid absurd consequence .... However, while I accept that the protective objective of the Act requires a generous interpretation with regard to the meaning of 'employee', it cannot be interpreted to mean that an employment relationship should be forced upon parties who did not intend creating one."

More recently the court in Denel (Pty) Ltd $v$ Gerber $^{19}$ held that it was obliged to determine "whether the label correctly represents the true legal relationship". The court held that Gerber who delivered services to Denel through a close corporation was in fact an employee on the "basis of the realities - on the basis of substance and not form or labels". The distinction between this case and the previous one is that in the Denel case the parties did not conclude a contract of employment for tax avoidance reasons. The simulated nature of their agreement had nothing to do with the true nature of their relationship. Gerber therefore fell within the definition of an employee even in the absence of a formal contract of employment.

In the Discovery Health case the court confirmed this position having regard to the constitutional framework that now is applicable so that persons who perform work for others can potentially fall within the notion of an "employee": 20

"To summarise: The protection against unfair labour practices established by section 23(1) of the Constitution is not dependent on a contract of employment. Protection extends potentially to other contracts, relationships and arrangements in terms of [which] a person performs work or provides personal services to another. The line between performing work "akin to employment" and the provision of services as part of a business is a matter regulated by the definition of 'employee' in section 213 of the LRA."

Therefore, the contract of employment may act as an admission ticket for labour law rights, but the absence of such a contract of employment will not necessarily present an insurmountable hurdle to accessing such rights. In

\footnotetext{
Supra, see in particular par 29-35.

Par 29-30.

[2005] 9 BLLR 849 (LAC).

Par 41.

21 See also White v Pan Palladium SA (Pty) Ltd supra, where the court held that the definition of "employee" in s 213 was not dependent solely on the conclusion of a contract recognized at common law as valid and enforceable (391B): "Someone who works for another, assists that other in his business and receives remuneration may, under the statutory definition, qualify as an employee even if the parties inter se have not yet agreed on all the relevant terms of the agreement by which they wish to regulate their contractual relationship."
} 
addition, it seems that workers cannot be said to be prejudiced by the continued important role of contracts of employment having regard to the courts' willingness to have regard of substance over form, the influence of the constitution on the law of contract and the courts' eagerness to develop the common law to provide for a reciprocal duty of good faith on employers and employees. These issues are considered below.

\section{Continued importance of the contract of employment}

Clearly the rationale for a contract ${ }^{22}$ is to be expressed in the assertion that it is a means by which an agreement ${ }^{23}$ between two parties may be enforceable in terms of the law. ${ }^{24}$ This valid and legal imperative must be taken into account as an adjunct to other valuable considerations.

Firstly, the entitlement of a party to enter into a contract of his/her own volition is expressive of the principle of freedom of contract and the liberty ${ }^{25}$ we as individuals are entitled to exercise in deciding the manner in which we organize our lives. ${ }^{26}$ The ability to enter into a contract is further underscored by the individual's constitutional rights. ${ }^{27}$ This principle is important to all individuals, whether working on the shop floor or being an executive in a managerial position.

Secondly, a contract of employment affords parties the opportunity of identifying their respective employment rights and duties, ${ }^{28}$ thereby providing certainty as to the ambit of the nature of the relationship going forward. Whilst no contract could ever be said to be drafted so as to be exhaustively prophetic

22 For purposes of this analysis references are, unless otherwise stated, to contracts of employment.

23 See Kleyn 1995 THRHR 27-29.

24 Christie 2, especially critical comments at fn 6 thereof.

25 In this regard, see comments by Hawthorne "The Principle of Equality in the Law of Contract" 1995 THRHR 157162 et seq; Epstein 1984 University of Chicago LR 954; Brassey "The Contractual Right to Work" 1982 ILJ 247; and Rycroft "Is There Still a Right to Terminate Employment on Notice Without Reasons?" 1989 SALJ 270272.

26 For a counter-argument that the inequality of bargaining power between the parties grants the employee a mere "fictional" freedom to contract see in general Kahn-Freund "A Note on Status and Contract in British Labour Law" 1967 MLR 635 639-640; Benjamin "The Contract of Employment and the Domestic Workers" 1980 ILJ 187; Collins 1986 ILJ (UK) 1; Elias 1982 CLP 112; Merrit "The Historical Role of Law in the Regulation of Employment Abstentionist or Interventionist?" 1982 AJLS 56 82; Forrest "Political Values in Individual Employment Law" 1980 MLR 361 363; Fox Beyond Contract: Work, Power and Trust Relations (1974) 182-184; and Rycroft and Jordaan 25.

27 Specific reference in this regard is had to sections $1,3,7,9,10,16,18,22$ and 23 of the Constitution of the Republic of South Africa, 1996. See also the limitation of such rights in terms of s 36. See Fidelity Guards Holdings (Pty) Ltd v Pearmain [1998] 3 BLLR 335 (SE) 343D-H; and Den Braven SA (Pty) Ltd v Pillay 20086 SA 229 (D) 253F and 254B-D. For an interesting discussion on the changing nature of the contract of employment see Rycroft "Rebel Without a Cause: The Changing Terrain of the Contract of Employment" paper presented at the 2008 SASLAW Conference.

28 Referred to as the so-called "two-tiered" structure: See Elias 1982 CLP 96 et seq; and Benjamin 1980 ILJ 187. Cf Selznick Law, Society and Industrial Justice (1969) 61. 
of all aspects likely to regulate the relationship, to have some frame of reference must surely be better than none at all. ${ }^{29}$ Significantly, since 1 January 2008 labour law in China requires employers to conclude written contracts with their employees ${ }^{30}$ which agreement must contain certain peremptory provisions, inter alia, health standards, minimum service levels and compensation in the event of dismissal. A similar scenario is evidenced by the provisions of section 29 of the Basic Conditions of Employment Act ${ }^{31}$ ("the 1997 Act"). The value of legal certainty is therefore furthered by the conclusion of valid and enforceable ${ }^{32}$ contracts. $^{33}$ After some controversy regarding classification of disputes and different causes of action the Supreme Court of Appeal stated that: ${ }^{34}$

"[A] claim, which exists as a fact, is not capable of being converted into a claim of a different kind by the mere use of language. Yet that is often what is sought to be done under the guise of what is called 'characterising' the claim. Where that word is used to mean 'describing the distinctive character of the claim' that is before the court, as a fact, then its use is unexceptionable. But when it is used to describe an alchemical process that purports to convert the

29 Whilst our law recognizes that there is no contract concluded until the parties agree on the material terms (Schoeman v IT Management Advisory Services (Pty) Ltd [2002] 7 BLLR 672 (LC) [12]) it also takes account of the fact that a tacit/implied contract can come about by the conduct of the parties where, eg an employer engaged an employee pursuant to approving a pro forma contract which it (the employer) adhered to despite the contract not having been signed and finalized (Mafihla v Govan Mbeki Municipality [2005] 4 BLLR 334 (LC) 341C-H).

30 An interesting article in this regard appears by Keene and Yu "PRC Passes Labour Contract Law" http//www.allens.com.au/pubs/pdf/asia/fochempjul07.pdf (accessed 200903-27). On the other hand, it has been stated that "the contract of employment is the regulatory pivot of the Australian labour law system" per Tham (La Throbe University) in "The Scope of Australian Labour Law and the Regulatory Challenges Posed by Self and Casual Employment" http:www.jil.go.jp/English/events_and_information/documents/clls04_ tham (accessed 2009-03-27).

3175 of 1997. Although making no specific express reference to "contract" per se, the statutory peremptory requirement of the employer supplying written particulars germane to the working relationship, if complied with, would provide the employee with greater rather than lesser certainty. In Rumbles v Kwa Bat Marketing (Pty) Ltd [2003] 8 BLLR 811 (LC) 815 the court held that $s 29$ of the BCEA required only written particulars and not a written contract of employment and noted further that there were no formalities to the creation of a binding contract of employment.

32 See Makhanya v University of Zululand 2009 JOL 23690 (SCA): "In this case the claim is for the enforcement of the common law right of a contracting party to exact performance of the contract. We know this because that is what it says in the particulars of claim. Whether the claim is a good one or a bad one is immaterial. Nor may a court thwart the pursuit of the claim by denying access to a forum that has been provided by law. A claim of that kind clearly falls within the ordinary power of the high court that is derived from the Constitution and the jurisdictional objection should have failed" (par 95). Furthermore in par 18: "Thus to summarize: - The Labour Forums have exclusive power to enforce LRA rights (to the exclusion of the high courts). - The high court and the Labour Court both have the power to enforce common law contractual rights. - The high court and the Labour Court both have the power to enforce constitutional rights so far as their infringement arises from employment."

33 Having due regard of the common-law principles and rules that seek to limit/eliminate unfairness in the making of a contract (as identified in Christie 16), including: quasi-mutual assent, misrepresentation and fraud, duress, undue influence, mistake, illegality and unenforceability.

34 The Makhanya $v$ University of Zululand case. 
claim into a claim of another kind then the word is abused". ${ }^{35}$

"In this case the claim is for the enforcement of the common law right of a contracting party to exact performance of the contract. We know this because that is what it says in the particulars of claim. Whether the claim is a good one or a bad one is immaterial. Nor may a court thwart the pursuit of the claim by denying access to a forum that has been provided by law. A claim of that kind clearly falls within the ordinary power of the high court that is derived from the Constitution and the jurisdictional objection should have failed"

Soon after this decision was handed down the constitutional court, in Vuyile Jackson Gcaba $v$ Minister of Safety and Security, ${ }^{37}$ had the opportunity to settle this matter once and for all. Whether the court succeeded in doing so remains to be seen. The court did state that the Labour Relations Act does not intend to destroy causes of action (which would include contractual remedies) ${ }^{38}$ but the court also emphasized that the constitution recognizes the need for specificity and specialization in a modern and complex society. ${ }^{39}$

Thirdly, allowing parties to engage freely in concluding contracts of employment is in the interests of social and public policy. This is not because such contracts are beyond any criticism in their form or content, ${ }^{40}$ but simply because they serve a practical and useful alternative to remedies ordinarily provided by courts, labour tribunals and legislation. ${ }^{41}$ Whilst the system of "selfregulation by contract", ${ }^{42}$ may be criticised as a weak form of government, it cannot be disputed that it is in the interests of the boni mores, and a tenet of our legal system to uphold the principle pacta sunt servanda. ${ }^{43}$ Although the

\footnotetext{
Par 72.

Par 95.
}

37 [2009] ZACC 26 (7 Oct 2009). The court had to decide whether the high court was correct in holding that it did not have the jurisdiction to entertain the application to review and set aside the decision of the South African Police Service not to appoint Mr Gcaba as station commissioner in Grahamstown. It therefore dealt with administrative law versus labour legislation and not with contractual rights as such.

38 Par 73: "Furthermore, the LRA does not intend to destroy causes of action or remedies and section 157 should not be interpreted to do so. Where a remedy lies in the High Court, section 157(2) cannot be read to mean that it no longer lies there and should not be read to mean as much. Where the judgment of Ngcobo $\mathrm{J}$ in Chirwa speaks of a court for labour and employment disputes, it refers to labour- and employment related disputes for which the LRA creates specific remedies. It does not mean that all other remedies which might lie in other courts like the High Court and Equality Court, can no longer be adjudicated by those courts."

39 Par 56: "Once a set of carefully-crafted rules and structures has been created for the effective and speedy resolution of disputes and protection of rights in a particular area of law, it is preferable to use that particular system." See also par 34 below, where Wallis AJA reigned in the development of the common law re unfair dismissal (SAMSA $v$ McKenzie (017/09) [2010] ZASCA 2 (15 Feb 2010)).

40 See obiter comments per Wallis AJ in Den Braven SA (Pty) Ltd v Pillay supra when referring to the remark by Didcott $J$ that: "[T]he ability of lawyers drafting agreements to predict with accuracy what a court will in the future regard as fair and reasonable in the light of facts that are not known at the time the agreement is drafted is limited" (261D).

41 Elias 1982 CLP 95

42 Per Selznick in fn 28 above.

43 See in this regard Burger v Central South African Railways 1903 TS 571 576; and Christie 20 and the authorities cited in fn 81 and fn 82 . An example of the spirit of sanctity being endorsed in our modern society is to be found in the case where our labour court has found that confirmation of an offer by acceptance thereof via an SMS is valid and binding (see 
unequal bargaining power in the employment relationship may result in some frowning upon this very foundation of the law of contract it must be remembered that this is not an absolute rule: In Barkhuizen $v$ Napier, ${ }^{44}$ the majority stated that the principle of pacta servanda sunt is not "a sacred cow that should trump all other considerations". ${ }^{45}$ The court held that contractual agreements, just as all other law, are subject to constitutional supervision or control. Therefore public policy may result in a contractual provision being invalid. In Parry v Astral Operations $L t d^{46}$ the labour court confirmed that:

"[p]ublic policy norms governing an employment relationship, which cannot be excluded by contract, include provisions that prescribe minimum terms and conditions of employment and the protection against unfair discrimination, dismissal and labour practices."

Fourthly, a characteristic of globalization ${ }^{47}$ has been the increase in atypical forms of employment ${ }^{48}$ and the "informal economy" workers is exacerbated by the absence of any nominal contractual framework they would otherwise be able to rely upon in order to enforce their rights as workers. It is submitted that their protection would be in the realm of section 23 of the Constitution ${ }^{50}$ and relevant ILO instruments. ${ }^{51}$

That the contract of employment is relevant, regard had to the above considerations, may conduce to the view it is deserving of protection. The advent of a constitutional dispensation ${ }^{52}$ in South Africa has strengthened this

Jafta $v$ Ezemvelo KZN Wildlife [2008] 10 BLLR 954 (LC) 975D-976B). See also Olivier in fn 2 above 7 .

4420075 SA 323 (CC).

45 Par 15. The boundaries of the constitutional court's supervision and control have been considered by some to be problematic. Eg. Cheadle "Labour Law and the Constitution" paper delivered at the 2007 SASLAW annual conference, has warned (par 6) that a distinction should be maintained between the legality and constitutionality of legislation and its application as such. This caveat was in response to the obiter dictum of the court in NEHAWU v University of Cape Town 2003 ILJ 95 (CC): "Interpretation is one thing but application is another. If the application of a right constitutes a constitutional matter, then every unfair dismissal is potentially constitutional fodder. This does not accord with the constitutional structure of the courts or for that matter with its own decisions in respect of fair trial rights in section 35(3). The statement was not necessary to the decision and probably was not intended".

462005 ILJ 1479 (LC) par 58.

47 See Calitz PER/PELJ 10 2/115 http://www.puk.ac.za/opencms/export/PUK/htm (accessed 2009-10-09).

$48 \mathrm{Eg}$, casual workers, self-employment, part-time work, temporary work, sub-contractors, home workers and temporary employment service providers.

49 Smit "Decent Work and the Promotion of Access to Social Protection for Workers in the Informal Economy - An International and Regional Perspective" 2007 TSAR 700.

50 See fn 71 below; and SANDU v Minister of Defence [2007] 9 BLLR 785 (CC) 789D. The deeming provision as provided for in terms of $\mathrm{s} 83$ of the Act 75 of 1997 (and s 200A of the LRA) is also indicative of a legislative attempt to address the situation of atypical workers by deeming "any category of persons" employees for purposes of the 1997 Act. Of course, if a worker has been "deemed" an employee, s 29 of the Act would be applicable and written particulars of employment are required.

$51 \mathrm{Eg}$, the ILO Declaration on Social Justice for a Fair Globalization adopted by the International Labour Conference at its $97^{\text {th }}$ Session, Geneva (10 June 2008).

52 See Carmichele v Minister of Safety and Security 20014 SA 938 (CC) par 39: "It needs to be stressed that the obligation of Courts to develop the common law, in the context of the $s$ 
view. Alternatively, given the analysis below, some would suggest that centuries of viewing the employment relationship as a mere "contractual account" has inadvertently lost sight of factors extraneous to the contract of employment which are in and of themselves sufficiently important and complex to simply render the contract of employment irrelevant. ${ }^{53}$ The prime reason for this has got to do with the quintessential feature of the status-based nature of the employment relationship. ${ }^{54}$

\section{BEYOND THE CONTRACT OF EMPLOYMENT}

\section{Background}

The socio-economic and legal constitutional fabric of the system with which labour law is so intricately embroidered ${ }^{55}$ gives rise to certain factors which affect the employment relationship. It is submitted that considerations such as the very nature of the employment contract per se, regard had to its statusbased history and its unique distinctiveness from other contracts ${ }^{56}$ render it inappropriate for the relationship between employee and employer to be governed purely according to the clinical legal dictates of law of contract which may disregard the unequal bargaining position of the parties on the one hand or on the other hand regard a dismissal to be lawful whilst disregarding the fairness thereof. Accordingly, it is befitting that labour law acknowledges the special nature of the employment contract and does so with due regard to relevant legislation and the Constitution. ${ }^{57}$

Firstly, a body of jurisprudence has developed importing into the common law of contract values and principles premised on fairness and equity, ${ }^{58}$ for example the right to a pre-dismissal hearing, ${ }^{59}$ the right to mutual trust and confidence $^{60}$ and the right not to be unfairly treated so as to constitute a

39(2) objectives, is not purely discretionary. On the contrary, it is implicit in s 39(2) read with s 173 that where the common law as it stands is deficient in promoting the $s 39(2)$ objectives, the courts are under a general obligation to develop it appropriately." This interpretation has, however, been criticized, refer to Smit "Towards Social Justice: An Elusive and a Challenging Endeavour" 2010 TSAR 1 par 3.

53 Collins 1986 ILJ (UK) 14; and Fourie 1979 THRHR 79.

54 Wedderburn 1993 ILJ 517; Erasmus "Refusing to Step Beyond the Confines of the Contract: The Jurisprudence of Adv Erasmus SC" 1985 ILJ 425 434; and Haysom and Thompson "Labouring Under the Law: South Africa's Farm Workers" 1986 ILJ 218 223-224.

55 Du Toit, Bosch, Woolfrey, Godfrey, Cooper, Giles, Bosch and Rossouw Labour Relations Law A Comprehensive Guide 5ed (2006) 58. See also Du Toit "Corporatism and Collective Bargaining in a Democratic South Africa" 1995 ILJ 785788.

56 Eg, general commercial agreements.

57 See Gcaba v Minister of Safety and Security 2009 ZACC 26 [65].

58 Olivier "The Relevance of Status and Contract for the Employment Relationship (Part II)" adapted version of an inaugural address delivered on 02 September 1992 at the Rand Afrikaans University (as it was then known) 23.

59 Boxer Superstores Mthatha v Mbenya [2007] 8 BLLR 693 (SCA) 696 [6]; and Old Mutual Life Assurance Co SA Ltd v Gumbi 20078 BLLR 699 (SCA) 701 [4].

60 Council for Scientific \& Industrial Research v Fijen [1996] 6 BLLR 685 (A). 
constructive dismissal. ${ }^{61}$ The imbuement of the common-law contract of employment with rights expressive of constitutional principles ${ }^{62}$ is clearly demonstrative of the contract of employment having evolved in terms of a constitutional dispensation. ${ }^{63}$

Secondly, whilst implied that the employer has the right to discipline the employee, acknowledged it must be that the source of such prerogative arises from the status relationship between the parties.$^{64}$ In practice a contract silent on disciplinary rules and procedures does not ride roughshod over the employer's right to take disciplinary action; neither does it entitle the employee to act with anything less than good faith toward the employer. ${ }^{65}$ It would be incumbent, in the absence of express disciplinary rules and procedures, at the very least to observe the guidelines ${ }^{66}$ as contained in the Code of Good Practice: Dismissal. ${ }^{67}$

Thirdly, and as correctly pointed out by Olivier, ${ }^{68}$ legislation, collective bargaining and the common law as developed by our dispute resolution fora and judicial system have and continue to influence the employment relationship and contract. Each one requires some consideration.

\section{Legislation}

Certain core labour legislation ${ }^{69}$ and social security legislation ${ }^{70}$ are legislative instruments ${ }^{71}$ impacting fundamentally on the employment relationship ${ }^{72}$

61 Murray $v$ Minister of Defence [2008] 6 BLLR 513 (SCA) [11] and [12]. See also MEC, Department of Roads \& Transport, Eastern Cape v Giyose [2008] 5 BLLR 472 (E) [23] et seq; and Nxele v Chief Deputy Commissioner, Department of Correctional Services [2008] 12 BLLR 1179 (LAC) 1194A.

62 Assuming these or similar rights are not expressly provided for by the parties themselves.

63 For general discussion on the constitutionalization of labour law see Cheadle in fn 45 above.

64 Olivier in fn 2 above 13. See also generally County Fair Foods (Pty) Ltd v CCMA [1999] 11 BLLR 1117 (LAC). Cf Sidumo v Rustenburg Platinum Mines Ltd [2007] 12 BLLR 1097 (CC).

65 See, eg, Standard Bank of South Africa Ltd v CCMA [1998] 6 BLLR 622 (LC) [39]-[42]; and SAPPI Novoboard (Pty) Ltd v Bolleurs [1998] 5 BLLR 460 (LAC) 462B. Cf comments by Hawthorne 2007 THRHR 172.

66 See, eg, Khula Enterprise Finance Ltd $v$ Madinane [2004] 4 BLLR 366 (LC) [11]; and SA Tourism Board $v$ CCMA [2004] 3 BLLR 272 (LC) [14].

67 Schedule 8 of the Labour Relations Act 66 of 1995 ("the Act"). An employer who does have a disciplinary code incorporated into the employment contract is held to be bound in terms of the provisions of such code (Denel (Pty) Ltd v Vorster 2004 ILJ 659 (SCA); and Dell v Seton (Pty) Ltd [2009] 2 BLLR 122 (LC) 127 [28]).

68 In fn 2 above 20 et seq. See also Clark 100; and Le Roux "Substantive Competence of Industrial Courts" 1987 ILJ 183197.

69 Such as Act 66 of 1995; Act 7 of 1997; the Promotion of Administrative Justice Act 3 of 2000; Employment Equity Act 55 of 1998 and the Skills Development Act 97 of 1998.

70 Occupational Health and Safety Act 85 of 1993; Unemployment Insurance Act 63 of 2001 and Workmen's Compensation Act 30 of 1941.

71 It is noteworthy that $s 1$ of the Act has as its purpose, inter alia, "the advancement and democratization of the workplace by fulfilling the primary objects of the [LRA]". These objects are, inter alia, to give effect to and regulate the fundamental rights conferred by the Constitution. Moreover, persons applying the Act's provisions are obliged to do so by giving effect to the primary purpose of the Act, complying with the Constitution and ILO 
regardless of a contract of employment or negotiated contractual provisions. ${ }^{73}$ The observation that legislation has a propensity to "distort" basis of the relationship should, however, be seen in the context, it is submitted, of addressing the inherent imbalance in the relationship and thereby contributing to defining and regulating the employment relationship in an advantageous manner. ${ }^{95}$ The preamble to the BCEA states that the aim of the Act is, inter alia, to give effect to the right to fair labour practices referred to in section 23(1) of the constitution. The preamble to the Labour Relations Act envisages a change to the law governing labour relations and in order to achieve such purpose effect will be given to, inter alia, the constitution, public international law obligations and a speedy dispute resolution procedure offered by the CCMA. It is "legislation based on the Constitution" so aptly pointed out by Van der Westhuizen $\mathrm{J}$ in $\mathrm{Gcaba}^{76}$ that is so important in the realization and giving effect to of the rights of parties within the labour-law framework in a manner that is fair to both parties ${ }^{77}$ that the objectives of the legislature, it is submitted, can begin to be met.

\section{Collective bargaining}

In addressing the imbalance of the power divide between the parties, ${ }^{78}$ collective bargaining clearly emphasizes the interests of the collective over the individual; evidence of which is to be found in the recognition afforded industrial activity in terms of the provisions of the LRA. ${ }^{79}$ Moreover, the binding nature of a collective agreement ${ }^{80}$ and the extension thereof ${ }^{81}$ is implied into the

obligations. On constitutionality of socio-economic rights, refer to Devenish "The Nature, Evolution and Operation of Socio-economic Rights in the South African Constitution" 2007 THRHR 8488 et seq.

72 As pointed out in the Den Braven SA (Pty) Ltd v Pillay supra, where Wallis AJ stated: "Problems that may arise from the disparate relationships of the parties are dealt with in a variety of ways and particularly by legislation" (251F).

73 Where, eg, parties agree to a restraint of trade clause, such clause, although prima facie valid and binding in terms of the employment contract, would ultimately have to pass constitutional muster in terms of showing that it does not unreasonably restrict the employee's right to freedom of economic activity (see the Fidelity Guards Holdings (Pty) Ltd v Pearmain supra; and the Den Braven SA (Pty) Ltd v Pillay supra 251F-G and 252D).

74 Olivier in fn 2 above 23, and especially fn 63.

75 See comments by Rycroft and Jordaan 46-47. See interesting remarks by Pascal Lokiec (University of Paris) on how French legislation has assisted with formally defining persons previously considered independent contractors as employees in "The Scope of Labour Law and the Notion of Employee: Aspects of French Law" http:www:jil.go.jp/English/events and information/documents/c//504 lokiec2.pdf 1-8 5 (accessed 2009-03-27). The extension of the definition of an employee to a resident foreigner in South Africa without a valid work permit is an interesting development in our law in this regard as established by

76 Par 1. the labour court in Discovery Health Limited v CCMA supra.

77 See NEHAWU v UCT 20033 SA (CC) [14].

78 Forrest 1980 MLR 363. See also Davies and Freedland "Changing Perspectives Upon the Employment Relationship in British Labour Law" in Barnard, Deakin and Morris (eds) The Future of Labour Law (2004) 129146.

79 Ss 64-77 Chapter IV. In this regard also see the LRA Explanatory Memorandum (Prepared by Ministerial Legal Task Team) (January 1995) 297-298.

80 S 31 of the Act. See Bravo Group Sleep Products (Pty) Ltd v CEPPWAWU [2009] 2 BLLR 
employment relationship of parties who find themselves within a bargaining unit covered by a particular agreement. ${ }^{82}$ The contract of employment serves almost as the product of the antecedent historical collective bargaining process. $^{83}$ Currently the lacuna in our labour law of the express lack of regulation between a workplace agreement and collective agreement ${ }^{84}$ is one that requires to be dealt with ${ }^{85}$ through the appropriate means of legislative intervention than private contractual remedies. On account of the fact that the contract of employment is determinative of the "outcome of the terms agreed between the employers and individual employees" it has been noted that Wedderburn is of the view that such contract remains of primary importance. ${ }^{86}$

\section{Common law influence}

The industrial law journals are replete with examples of fair labour practice jurisprudence ${ }^{87}$ that has been developed by the industrial court since the eighties in giving effect to the intent of the Wiehahn Commission. ${ }^{88}$ Debate ensued with the establishment of the Labour Court as a court of law and equity ${ }^{89}$ as to the precise impact of the noun "equity" on its jurisdiction. ${ }^{90}$ It is submitted that the rationale for dispensing not only law but also equity in matters that come before it is a means, albeit implied, of addressing the inherent power imbalance between the parties in the employment relationship which is distinctive from other propriety and commercial relationships inasmuch as "human beings exchange not objects but themselves". ${ }^{91}$

114 (LC) [20].

81 S 32 of the LRA.

82 See Du Toit et al 271; and SA Polymer Holdings (Pty) Ltd v Llale 1994 ILJ 277 (LAC) 280B.

83 In this regard see Deakin "The Comparative Evolution of the Employment Relationship" 12 17 http://www.cbr.cam.ac.uk/pdf/WP317.pdd (accessed 2009-10-05). See also Olivier "Inchoate Regulation of Worker Participation in South Africa: The Quest for an Alternative Approach" Festschrift_Neu.indd Abs1.449 (2005-06-24) 449 457-458; and Fourie 1979 THRHR 79 .

84 Olivier Festschrift_Neu.indd Abs1.449 (2005-06-24) 449 457-458.

85 In the absence of contractual terms obliging the parties through their duly appointed representatives to embark on the necessary collective bargaining. See Smit 2007 TSAR 714.

86 Van Jaarsveld "Contract in Employment: Weathering Storms in Mixed Jurisdictions? Some Comparative Thoughts" 2008 Electronic Journal of Comparative Law 21-22 http://www.ejcl. org/121/art121-26. pdf 21 (accessed 2009-10-09).

87 Eg, MAWUSA v Mauchle (Pty) Ltd 1980 ILJ 227 (IC) 239D-F 246D-F; MAWUSA v Screenex Wire Weaving Manufacturers (Pty) Ltd 1985 ILJ 75 (IC) 88G-89B; and Ray's Forge \& Fabrication (Pty) Ltd v NUMSA 1989 ILJ 762 (IC) 770C-773H. Also see Cohen "Understanding Fair Labour Practices - NEWU v CCMA" 2004 SAJHR 482.

88 Wallis in fn 6 above 1-9. See also: Brassey "The New Industrial Court" 1980 ILJ 75 79; and Rycroft 1989 SALJ 272.

$89 \mathrm{~S} 151$ of the LRA.

90 Du Toit et al 153 in particular the authorities mentioned in fn 501.

91 Per Sinzheimer in Clark 82 in fn 3 above. The imbalance which is found in the employment relationship, consisting of the so-called two-tier structure (Elias 1982 CLP 96) is an imbalance which is not, it is submitted, inherent, all other things being equal, in a general commercial agreement. See Collins 1986 ILJ (UK) 12-13; Fox 153-154; and Elias 1982 CLP 110. 
The current manner in which labour jurisprudence has developed ${ }^{92}$ can best be captured by the remarks made by Froneman J in Nakin v MEC, Department of Education, Eastern Cape Province ${ }^{93}$ that:

"as far as the development of the common-law contract of employment in accordance with the Constitution is concerned, the beneficial insights have mostly been flowing to the civil courts from developments in the Labour Court and from the concretization of fair labour standards in labour legislation and general employment practices, not the other way round".

Put differently, a further dimension, other than mere common-law contractual obligations is now taken into account, namely considerations of fairness. ${ }^{95}$ Clearly, through the judgments of our courts we see our judges going further afield than merely dwelling, confining and limiting themselves to the employment contract when called upon to ascertain the mere relationship between the parties. ${ }^{96}$ This is no more evident than in the sphere of public sector employees whose employment is statutorily regulated in terms of the Public Service Act ${ }^{97}$ ("the Act"), and whose contract is said to be a "status contract". ${ }^{98}$ Although status in nature, section 17 of the Act still makes it obligatory for the termination of the relationship to be exercised in accordance with the LRA. The constitutional court ${ }^{99}$ in Transnet Ltd $v$ Chirwa ${ }^{100}$ found that the dismissal of a public sector employee did not constitute an administrative act for purposes of the Promotion of Administration of Justice Act ${ }^{101}$ and that where a matter falls within the ambit of the jurisdiction of the labour court, the labour court has exclusive jurisdiction. ${ }^{102}$ The decision subsequently sparked widespread judicial and academic discussion and discord on the question of

92 Which development is further underscored by the statutory entrenchment of unfair dismissal and unfair labour practice, in terms of the Chapter VIII of the Act.

932008 ILJ 1426 (E).

941443 [36].

95 In this regard the decision of Discovery Health Ltd $v$ CCMA supra is an opposite example, where the court, in having found there to have been a valid contract of employment (1492 [35]), considered the nature of the employment relationship between the parties taking into account issues such as fair labour practices (1490 [30] - 1491 [34]), the Constitution (1493 [40] - 1494) and ILO standards (1494 [43] et seq). Cf the decision by the court in "Kylie" $v$ CCMA [2008] 9 BLLR 870 (LC) that found that the protection afforded an employee in terms of $s 23$ of the constitution could not be afforded a sex worker, who although, an employee in terms of the statutory definition of "employee", was not entitled to protection under labour legislation since same was contra bonos mores and contrary the Sexual Offences Act 23 of 1957.

96 As correctly pointed out by Professor Thomas, constitutional acknowledgment of the fact that our common law is not static but is "a living and developing body of law" is recognized by the provisions of s 39(2) of the Constitution. Thomas "The South African Common Law into the Twenty-first Century" 2005 TSAR 292296.

97103 of 1994, as amended by the Public Service Regulations of 2001 in terms of Government Notice R937 of 2009-10-02.

98 Olivier in $\mathrm{fn} 2$ above 14, fn 65, and also with reference to Maine's theory of a modern society evidencing a movement away from status toward contract commensurate with the rights and obligations a modern society imposes upon individuals (see Olivier in fn 2 above 3).

99 In a divided decision.

100 [2008] 2 BLLR 97 (CC).

1013 of 2000

102 See reasoning per Skweyiya J [40] and Ngcobo J [103-104]. 
the $f_{0 r}{ }^{103}$ in which a public sector employee is obliged to pursue a dispute. ${ }^{104}$ The constitutional court in the Gcaba case ${ }^{105}$ decision purports to create clarity in this regard by relegating labour and employment disputes to the labour court $^{106}$ and so-called non-labour and non-employment related remedies to the high court. ${ }^{107}$ It is a question of debate, beyond the scope of this article, as to whether Gcaba can be said to have settled the law in this regard.

What the Supreme Court of Appeal has been firm about is that the traditional view of the contract of employment must be reconsidered. In Murray $v$ Minister of Defence, ${ }^{108}$ in a case that dealt with a commander in the South African Navy who is not covered by the Labour Relations Act, the court was willing to recognize that a resignation could, in terms of the common law, constitute a constructive dismissal. The court emphasized the fundamental right of everyone to fair labour practices in section 23(1) of the Bill of Rights. Although the parties in that case had agreed that the plaintiff could rely directly on the constitutional rights to fair labour practice and dignity the court preferred to ground the case in the contract of employment: ${ }^{109}$

"it is in my view best to understand the impact of these rights on this case through the constitutional development of the common-law contract of employment. This contract has always imposed mutual obligations of confidence and trust between employer and employee. Developed as it must be to promote the spirit, purport and objects of the Bill of Rights, the commonlaw of employment must be held to impose on all employers a duty of fair dealing at all times with their employees - even those the LRA does not cover" (authors' own emphasis).

The court expressly confirmed the supremacy of the Constitution, also in contractual matters, and did so in unequivocal terms which are therefore worthwhile repeating here: ${ }^{110}$

"This follows from the fact that all contracts are subject to constitutional scrutiny: this includes employment contracts outside the LRA. Whether an employer dismisses such an employee in violation of the right to fair labour practices, or unfairly precipitates a resignation, is a matter of form, not constitutional substance. And it is no longer necessary under either the

103 Namely, the labour court or high court.

104 See, eg Nakin v MEC, Department of Education, Eastern Cape Province [2008] 5 BLLR 489 (Ck); Mohlaka v Minister of Finance [2009] 4 BLLR 348 (LC) [11]; Mogothle $v$ The Premier of the Northwest Province [2009] 4 BLLR 331 (LC) [28] and [29]; Tsika v Buffalo City Municipality [2009] 3 BLLR 272 (E) 293E-295G; Mlokoti v Amathole District Municipality [2009] BLLR 168 (E) and the authorities cited 172A-B; 173A-D and 173G.

105 See Gcaba v Minister of Safety and Security supra.

106 Gcaba v Minister of Safety and Security supra [72] and [73].

107 Ibid.

1082008 (11) BCLR 1175 (SCA).

109 Par 5.

110 Par 9-11. See also an earlier case that dealt with the issue of constructive dismissal $W L$ Ochse Webb \& Pretorius (Pty) Ltd v Vermeulen [1997] 2 BLLR 124 (LAC) 128: "Such a dichotomy [ie, a case where a dismissal might be unlawful under the common law, but still fair under the Act] in approach is not helpful. Employers and employees should not be expected to arrange their affairs in a schizophrenic manner, where one set of rules applies when the common law holds sway, whilst another does when the Act applies. Furthermore, in my respectful view, the divergence in approach is avoidable." 
constitutionally developed common law or under the LRA to continue to invoke concepts such as repudiation (as was previously necessary) to unmask the true substance of the parties' dealings. That substance, as was pointed out before the 1995 LRA, is that the law and the Constitution of the Republic of South Africa, 1996 impose 'a continuing obligation of fairness towards the employee on ... the employer when he makes decisions affecting the employee in his work'. The obligation has both a formal, procedural and substantive dimension; it is now encapsulated in the constitutional right to fair treatment in the workplace."

One must be conscious of the fact that the case of Murray is one where the contract of employment did in fact fall "outside the LRA". Consequently, in SAMSA v McKenzie ${ }^{111}$ the court limited the effect of Murray to employees or workers not covered by the labour legislation. This limits the impact of the constitutional right to fair labour practices on the majority of employment contracts but it does provide a foothold for those (often vulnerable groups) who provide services to another whilst not falling squarely within the statutory definitions of "employees". In the McKenzie case it appears that the supreme court of appeal has now reigned in the development of the common law regarding the contract of employment (in casu Mr McKenzie contended that his contract of employment was subject to a (implied) term that it would not be terminated without just cause): ${ }^{112}$

"I do not think that any of the cases I have referred to [including Gumbi, Boxer Superstores and Transman $v$ Dick] can be said to have decided authoritatively that the common law is to be developed by importing into contracts of employment generally rights flowing from the constitutional right to fair labour practices. It is uncontroversial that the LRA is intended to give effect to that constitutional right and I see no present call, certainly not in this case, for the common law to be developed so as to duplicate those rights (at least so far as it relates to employees who are subject to that Act)."

\section{CONCLUSION}

The status relationship has found support for the contention that the contract of employment is clothed in a fiction of equality akin to an ordinary commercial transaction. ${ }^{113}$ This may be so. The contract of employment is not a panacea to the employment relationship. This, however, does not render it nugatory. Neither does it render it irrelevant.

When detailing the rights and obligations of the parties the contract of employment can and, in fact, must be interpreted and applied "consistently with the Constitution and the LRA". ${ }^{114}$ The "Achilles heel" which has arisen from the status relationship has actually become the strength in propelling our courts to

111 Fn 39: "Murray seems to me to be authority for no more than the proposition that an employee who is not subject to the LRA enjoys the same right as other employees not to be constructively dismissed, whatever else might have been said en passant. It is possible that there is some need to develop the common law by importing into the contract of such employees terms that give effect to their right to fair labour practices but that is not a matter that need now concern us."

112 Par 55.

113 Davies and Freedland 25; and Clark 94.

114 Per Pillay J in Mohlaka $v$ Minister of Finance supra [25]. 
depart from general common-law principles to give effect to the uniqueness of the employment relationship, ${ }^{115}$ whether same is evidenced by a written or verbal agreement. In so doing the parties (in atypical and other standard employment relationships) are accorded greater protection within a labour law framework informed by constitutional law imperatives.

The labour court's assertion that the contract of employment is not the sole ticket for admission into the golden circle reserved for "employees"116 and that the statutory definition of "employee" is no longer (if it ever was) rooted in a contract of employment is therefore accurate. This does not, however, detract from the expediency of a modern contract of employment.

115 Selznick 70; Mogothle $v$ The Premier of the Northwest Province supra [24]; and Deakin 34 http://www.cbr.cam.ac.uk/pdfWP 203.pdf (accessed 2009-10-05).

116 See the Discovery Health Limited v CCMA supra par 49. 